\title{
Inactivation of Dynorphin-(1-8) in Isolated Preparations by Three Peptidases
}

\author{
Hiroaki NUMATA, Toyokazu HIRANUMA and Tetsuo OKA* \\ Department of Pharmacology. School of Medicine. Tokai University. \\ Isehara 259-11, Japan \\ Accepted May 6. 1988
}

\begin{abstract}
Inactivation of dynorphin-(1-8) in three in vitro isolated preparations. guinea-pig ileum, mouse vas deferens and rabbit vas deferens, was estimated by employing the relatively specific inhibitors of enkephalin-hydrolyzing enzymes. All three enzyme inhibitors, amastatin, captopril and phosphoramidon, significantly enhanced the inhibitory potency of dynorphin-(1-8) in the three isolated preparations. The magnitude of the enhancement of the dynorphin potency by captopril was significantly higher than that by either amastatin or phosphoramidon in guinea-pig ileum; that by amastatin was significantly higher than that by either captopril or phosphoramidon in rabbit vas deferens; and that by amastatin was similar to that by captopril, but significantly higher than that by phosphoramidon in mouse vas deferens. The $K_{e}$ values of three antagonists, naloxone. Mr 2266 and ICl 154129, against dynorphin-(1-8) in the presence of the three peptidase inhibitors indicated that dynorphin-(1-8) acted on kappa receptors in guinea-pig ileum and on both kappa and delta receptors in mouse vas deferens. Since amastatin. captopril and phosphoramidon produced the naloxone-reversible inhibition of contractions of guinea-pig ileum in the presence of dynorphin-(1-8), all three dynorphin-inactivating enzymes were indicated to be located very close to kappa receptors.
\end{abstract}

Enkephalins have been shown to be inactivated by three enzymes, amastatin-sensitive aminopeptidase, captopril-sensitive peptidyl dipeptidase A (angiotensin I converting enzyme, kininase II, peptidyldipeptide hydrolase: EC 3.4.15.1) and phosphoramidonsensitive endopeptidase-24.11 ("enkephalinase"; EC 3.4.24.11), in three in vitro isolated preparations, guinea-pig ileum (1), mouse vas deferens (2) and rat vas deferens (3). Since these enkephalin-hydrolyzing enzymes are located very close to opioid receptors $(1-3)$, these enzymes are suggested not only to inactive the exogenously given enkephalin in the vicinity of opioid receptors but also suggested to play important roles in the termination of the action on opioid receptors of the enkephalin released from presynaptic nerve terminals.

\footnotetext{
* To whom reprint requests should be addressed.
}

Additionally. enkephalin has been demonstrated to be almost exclusively hydrolyzed by these three enzymes, since enkephalin remains intact almost totally after it is in cubated with ileal or striatal membrane preparations of guinea-pig for $60 \mathrm{~min}$ at $37^{\circ} \mathrm{C}$ in the presence of the inhibitors against these three enzymes, although enkephaiin is completely hydrolyzed and free tyrosine and the Tyr-Gly-Gly fragment are produced when the incubation mixture does not contain the peptidase inhibitor (4).

Dynorphin-(1-8), another endogenous opioid peptide, has been suggested to be also inactivated by peptidases in isolated preparations such as rabbit vas deferens since its inhibitory action on the electrically-evoked contractions of the isolated preparation has been shown to be significantly enhanced by the pretreatment of the preparation with the mixture of peptidase inhibitors $(5,6)$. The 
enzyme involved in the inactivation of dynor phin-(1-8), however, is unknown at present In the present investigation, therefore, it was examined whether or not dynorphin-(1-8) was inactivated by three enkephalin-hydrolyzing enzymes in three isolated preparations guinea-pig ileum, mouse vas deferens and rabbit vas deferens.

Additionally, the preference of the opioidreceptor type by dynorphin-(1-8) was reexamined in isolated preparations in the presence of peptidase inhibitors by employing the three opioid antagonists, since dynorphin(1-8) had been reported to act on either kappa receptors in the preliminary experiments (7) or a different opioid-receptor type than the three classical opioid-receptor types, mu, kappa and delta type (8), and dynorphin$(1-9)$ had been indicated to act on both kappa and delta receptors (9).

Moreover, it was estimated in the present investigation whether or not dynorphininactivating enzymes were located very close to kappa receptors in guinea-pig ileum, since enkephalin-inactivating enzymes had been indicated to be located very close to mu receptors in guinea-pig ileum in the previous investigation (1).

\section{Materials and Methods}

Chemicals: Gifts of compounds which were gratefully received were dynorphin(1-8) from Prof Y. Kiso, Kyoto Pharmaceutical University (Kyoto); ICl 154129 (N.Ndiallyl-Tyr-Gly- $\psi$ - $\left(\mathrm{CH}_{2} \mathrm{~S}\right)$ - Phe - Leu) (where $\psi-\left(\mathrm{CH}_{2} \mathrm{~S}\right)$ signifies replacement of the amide $\mathrm{CO}-\mathrm{NH}$ bond by $\mathrm{CH}_{2} \mathrm{~S}$ ) from Dr. J.W. Holaday, Walter Reed Army Inst. Res. (Washington, D.C.. U.S.A.): Mr 2266 [(-)-2-(3furylmethyl) - 5.9 - diethyl - 2' - hydroxy - 6.7 benzomorphan)] from Nippon $\mathrm{CH}$ Boehringer Sohn Co., Ltd. (Osaka): and captopril and naloxone from Sankyo Company (Tokyo). Amastatin and phosphoramidon were purchased from Peptide Institute, Inc. (Minoh).

In vitro isolated preparations: Male ICR$\mathrm{JCL}$ mice weighing $30-50 \mathrm{~g}$, male Hartley guinea-pigs weighing $300-600 \mathrm{~g}$, and male Japanese White rabbits weighing $2.5-3.5 \mathrm{~kg}$ were used for this study. The vasa deferentia from mice or rabbits, and the myenteric plexus-longitudinal muscle strip of guinea- pig ileum were prepared and set up for electrical stimulation as described previously $(10$. 11). The \% inhibition of electrically-evoked muscle contrations produced by an opioid peptide was plotted against the log concentration of the peptide to estimate the IC50 (concentration of the opioid peptide to produce $50 \%$ inhibition of contractions). Amastatin. captopril or phosphoramidon at the final concentration of $1 \mu \mathrm{M}$ each was employed as an inhibitor of each peptidase in the present investigation since the previous studies had shown that the enkephalinhydrolyzing aminopeptidase, peptidyl dipeptidase $A$ and endopeptidase-24.11 were inhibited almost completely with $1 / / \mathrm{M}$ of amastatin, $1 \mu \mathrm{M}$ of captopril, and $1 \mu \mathrm{M}$ of phosphoramidon, respectively (1-4). Either a peptidase inhibitor or the mixture of two or three peptidase inhibitors was given $10 \mathrm{~min}$ before the opioid administration. The ratio of the potency and the \% difference. shown in the tables, were calculated from the following fomulas: ratio of potency $=\mid C 50$ before additional treatment/IC50 after additional treatment and \% difference $=[($ IC50 before additional treatment-IC50 after additional treatment)//C50 before additional treatment] $\times$ 100. The statistical significance of $\%$ differences between IC 50 values of two adjacent groups shown in the tables was determined by the paired Student's $t$-test. The $\mathrm{K}_{\mathrm{e}}$ (equilibrium dissociation constant) values of opioid antagonists against dynorphin-(1-8) were determined by the 'single' dose method (12).

\section{Results}

Enhancing effects of peptidase inhibitors on the potency of dynorphin-(1-8): Dynorphin-(1-8) dose-dependently inhibited the electrically-evoked contractions of all isolated preparations emploved in the present investigation. Its $1 \mathrm{C} 50$ value in guinea-pig ileum. mouse vas deferens and rabbit vas deferens was significantly decreased by the pretreatment of the preparation with mixture of three peptidase inhibitors, amastatin, captopril and phosphoramidon, at the final concentration of $1 \mu \mathrm{M}$ each at $10 \mathrm{~min}$ before the dynorphin administration (Table 1). Each peptidase inhibitor was then administered individually in the following experiments in 
order to determine which peptidase inhibitor had an enhancing effect on the inhibitory potency of dynorphin- (1-8).

In three isolated preparations, especially in guinea-pig ileum, the $1 \mathrm{C} 50$ value of dynorphin-(1-8) in one preparation was sometimes markedly different from that in another in the absence of the peptidase inhibitor. Thus, the mean of the IC50 values of dynorphin-(1-8) in one control group was sometimes prominently different from that in the other control group (Tables 2, 3 and 4). When the effect of a particular peptidase inhibitor on the inhibitory potency of dynorphin was examined, therefore, the IC50 values of dynorphin before and after the addition of a particular peptidase inhibitor were estimated in the same preparation.

All three peptidase inhibitors significantly enhanced the inhibitory potency of dynorphin-(1-8) in either guinea-pig ileum (Table 2 ). mouse vas deferens (Table 3 ) or rabbit vas deferens (Table 4).

In guinea-pig ileum, the magnitude of the

Table 1. Enhancing effects of peptidase inhibitors on the inhibitory potency of dynorphin-(1-8) in isolated preparations

\begin{tabular}{|c|c|c|c|c|}
\hline \multirow{2}{*}{ Preparations } & \multirow{2}{*}{$N: 1$} & \multicolumn{2}{|c|}{$1 C 50(n M)$} & \multirow{2}{*}{$\begin{array}{l}\text { Ratio of } \\
\text { potency }\end{array}$} \\
\hline & & Without inhibitors & With inhibitorsh & \\
\hline $\begin{array}{l}--- \\
\text { Guinea-pig ileum }\end{array}$ & 5 & $-320 \pm 160$ & $10.6 \pm 4.7$ & $43.1 \pm 15$ \\
\hline Mouse vas deferens & 4 & $91.8 \pm$ & $7.93 \pm 0.45$ & $11.6 \pm 1.0$ \\
\hline Rabbit vas deferens & 4 & $2090 \pm 1400$ & $104 \pm 80$ & $26.4 \pm 3.9$ \\
\hline
\end{tabular}

Each value represents the mean \pm S.E. "Number of experiments. LThe mixture of three peptidase inhibitors, amastatin, captopril and phosphoramidon, at the final concentration of $1 \mu \mathrm{M}$ each was given $10 \mathrm{~min}$ before the dynorphin administration. "IC50 without inhibitors/IC50 with inhibitors.

Table 2. The enhancing effects of peptidase inhibitors on the inhibitory potency of dynorphin-(1-8) in guinea-pig ileum

\begin{tabular}{llccc}
\hline Inhibitors & $\mathrm{N}^{\mathrm{at}}$ & $1 \mathrm{C} 0(\mathrm{nM})$ & Ratio of potency & \% Difference \\
None & 7 & $884 \pm 54$ & 1 & - \\
Amastatin & 7 & $464 \pm 27$ & $1.86 \pm 0.12$ & $45.1 \pm 3.4^{* * *}$ \\
None & 8 & $323 \pm 10$ & 1 & $79.8 \pm 2.6^{* * *}$ \\
Captopril & 8 & $58.0 \pm 16$ & $5.58 \pm 0.75$ & $22.9 \pm 5.0^{* * *}$ \\
None & 6 & $98.7 \pm 28$ & 1 & $1.33 \pm 0.086$ \\
Phosphoramidon & 6 & $73.0 \pm 17$ &
\end{tabular}

Each value represents the mean \pm S.E. a Number of experiments. ***P<0.01.

Table 3. The enhancing effects of peptidase inhibitors on the inhibitory potency of dynorphin-(1-8) in mouse vas deferens

\begin{tabular}{llll}
\hline Inhibitors & $1050(\mathrm{nM})$ & Ratio of potency & \% Difference \\
None & - & 1 & $54.8 \pm 5.4^{* *}$ \\
Amastatin & $69.6 \pm 19$ & $2.45 \pm 0.30$ & \\
None & $26.7 \pm 3.7$ & 1 & $54.0 \pm 6.7^{* *}$ \\
Captopril & $50.5 \pm 8.0$ & $2.50 \pm 0.33$ & $28.2 \pm 3.4^{* * *}$ \\
None & $20.7 \pm 3.4$ & 1 & \\
Phosphoramidon & $72.7 \pm 18$ & $1.42 \pm 0.071$ & \\
\hline
\end{tabular}

Each value represents the mean \pm S.E. of 8 experiments. ${ }^{* *} \mathrm{P}<0.01$ 
Table 4. The enhancing effects of peptidase inhibitors on the inhibitory potency of dynorphin-(1-8) in rabbit vas deferens

\begin{tabular}{lccc}
\hline Inhibitors & $1 \mathrm{C} 50(\mu \mathrm{M})$ & Ratio of potency & $\%$ Difference \\
\cline { 2 - 3 } None & $0.578 \pm 0.18$ & 1 & $82.4 \pm 2.3^{* * *}$ \\
Amastatin & $0.107 \pm 0.039$ & $6.30 \pm 1.2$ & $50.5 \pm 6.1^{* * *}$ \\
None & $1.07 \pm 0.51$ & 1 & $30.7 \pm 3.7^{* *}$ \\
Captoprit & $0.491 \pm 0.26$ & 1 & \\
None & $1.34 \pm 0.67$ & $1.46 \pm 0.081$ & \\
Phosphoramidon & $0.949 \pm 0.46$ & $1 * 0.42$ & \\
\hline
\end{tabular}

Each value represents the mean \pm S.E. of 5 experiments. ${ }^{* *} \mathrm{P}<0.01$.

enhancement of the dynorphin potency by amastatin was significantly higher than that by phosphoramidon, but significantly lower than that by captopril (Table 2).

The degree of the augmentation of the dynorphin potency by amastatin was similar to that by captopril, but significantly higher than that by phosphoramidon in mouse vas deferens (Table 3 ).

In rabbit vas deferens, the magnitude of the enhancement of the dynorphin potency by amastatin was significantly higher than that by captopril, and that by captopril was significantly higher than that by phosphoramidon (Table 4).

The inhibitory action of the peptidase inhibitor on contractions of guinea-pig ileum in the presence of dynorphin-(1-8): Either amastatin, captopril or phosphoramidon inhibited the electrically-evoked contractions of guinea-pig ileum in the presence of dynorphin-(1-8) (Fig. 1), although these peptidase inhibitors by themselves did not depress the contractions in the absence of an opioid peptide (figures were not shown). The magnitude of the inhibition by each peptidase inhibitor, although it was slightly altered by changing the administration order of the peptidase inhibitor, was the highest by captopril. the lowest by phosphoramidon and intermediate by amastatin (Fig. 1). The inhibition induced by peptidase inhibitors in the presence of dynorphin-(1-8) was antagonized by naloxone (Fig. 1). The degree of the antagonism by naloxone was not complete in some preparations as shown in Fig. 1, but complete in other preparations. The apparent incomplete antagonism by naloxone was likely to be produced by the agonistic action

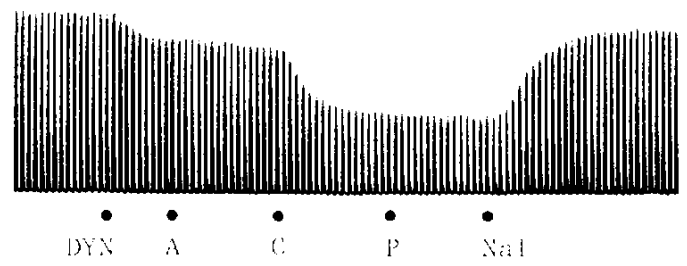

Fig. 1. Naloxone-reversible inhibitory actions of peptidase inhibitors on electrically-evoked contractions of guinea-pig ileum in the presence of dynorphin-(1-8). Compounds were given to the bath at the dot. DYN. 5 nM of dynorphin-(1-8). A, $1, \mu \mathrm{M}$ of amastatin. C. $1 / \mu \mathrm{M}$ of captopril. P. $1, \alpha \mathrm{M}$ of phosphoramidon. Nal, $1 / \mathrm{M}$ of naloxone.

of relatively high doses of naloxone on some preparations since dynorphin-(1-8) at doses below $5 \times 10^{-9} \mathrm{M}$ in the presence of the three peptidase inhibitors did not inhibit the contractions at all in all preparations after the administration of relatively high doses (e.g., $10^{-6} \mathrm{M}$ ) of naloxone which produced the slight inhibition of contractions by itself in some preparations.

The $K_{8}$ values of opioid antagonists against dynorhin-(1-8) in the presence of peptidase: The $K_{e}$ values against dynorphin-(1-8) of naloxone, which had been shown to have a high affinity to mu receptors (13), were relatively high, while those of $\mathrm{Mr} 2266$. which had been reported to have a high affinity to both mu and kappa receptors (13), were relatively low in guinea-pig ileum (Table 5). Additionally, the $K_{e}$ values of $I C l 154129$, which had been found to have a relatively high affinity to delta receptors, a low affinity to mu receptors, and a very low affinity to kappa receptors (13), were very high in 3 among 6 preparations and they were not able 
Table 5. The K. values of naloxone. Mr 2266 and ICI 154129 against dynorphin-(1-8) in isolated preparations

\begin{tabular}{|c|c|c|c|}
\hline \multirow{2}{*}{ Preparations } & & $K_{e}(n M)$ & \\
\hline & Naloxone & $\operatorname{Mr} 2266$ & ICl 154129 \\
\hline Guinea-pig ileum & $16.6 \pm 3.6$ & $4.42 \pm 1.1$ & —— \\
\hline Mouse vas deferens & $41.3 \pm 7.9$ & $3.67 \pm 0.76$ & $614 \pm 110$ \\
\hline
\end{tabular}

The $K_{e}$ values were estimated in the presence of the mixture of three peptidase inhibitors, amastatin, captopril and phosphoramidon. at the final concentration of $1 \mu \mathrm{M}$ each. Each value represents the mean $\pm S$.E. of 4 experiments. "Antagonism by $\mathrm{ICl} 154129$ at the dose of $10 \mu \mathrm{M}$ was not observed in 3 among 6 preparations, and $K_{n}$ values in the residual 3 preparations were 9.43, 12.7 and $23.3 \mu \mathrm{M}$.

to be estimated in the remaining 3 preparations of guinea-pig ileum because of no antagonism by $\mathrm{ICl} 154129$ (Table 5).

In mouse vas deferens, the $K_{c}$ values against dynorphin-(1-8) of naloxone. $\mathrm{Mr}$ 2266 and $\mathrm{ICl} 154129$ were relatively high, relatively low and relatively low, respectively (Table 5).

\section{Discussion}

The present investigation indicates that dynorphin-(1-8) can be inactivated by three enzymes, amastatin-sensitive aminopeptidase, captopril-sensitive peptidyl dipeptidase A and phosphoramidon-sensitive endopeptidase-24.11, in three in vitro isalated preparations, guinea-pig ileum, mouse vas deferens and rabbit vas deferens, since the inhibitory potency of dynorphin-(1-8) has been shown to be significantly enhanced by the pretreatment of the preparation with either amastatin. captopril or phosphoramidon in all three preparations.

The fact that the magnitude of the enhancement of the dynorphin potency by captopril was significantly higher than that by either amastatin or phosphoramidon in guinea-pig ileum suggests that captopril-sensitive peptidyl dipeptidase A plays the most important role in the inactivation of dynorphin-(1-8) in guinea-pig ileum. However, the important role of amastatin-sensitive aminopeptidase as well as captopril-sensitive enzyme in the inactivation of dynorphin-(1-8) in mouse vas deferens is suggested by the finding that the degree of the enhancement of the dynorphin potency by amastatin was similar to that by captopril but significantly higher than that by phosphoramidon in mouse vas deferens. In rabbit vas deferens, amastatin-sensitive aminopeptidase is likely to play the most important role in the inactivation of dynorphin(1-8) since the magnitude of the augmentation of the dynorphin potency by amastatin has been shown to be significantly higher than that by either captopril or phosphoramidon. The minor role of phosphoramidonsensitive endopeptidase-24.11 in the inactivation of dynorphin-(1-8) in all three preparations is indicated by the observation that the magnitude of the enhancement of the dynorphin potency by phosphoramidon was lower than that by either amastatin or captopril in the three preparations.

The data in the present investigation along with those obtained previously $(14,15)$ show that the relative importance of the three enzymes in the inactivation of dynorphin$(1-8)$ in guinea-pig ileum is different from that of either [Met $\left.{ }^{5}\right]$ - or [Leu ${ }^{5}$-enkephalin since the magnitude of the enhancement of the inhibitory potency of both [Met ${ }^{5}$ - and [Leu ${ }^{5}$-enkephalin by amastatin has been shown to be significantly higher than that by either captopril or phosphoramidon in guineapig ileum $(14,15)$. Additionally, the relative importance of the three enzymes in the inactivation of dynorphin-(1-8) in mouse vas deferens is different from that of $\left[\mathrm{Met}^{5}\right]$ enkephalin but similar to that of [Leu $\left.{ }^{5}\right]$ enkephalin since the magnitude of the augmentation of the $\left[\mathrm{Met}^{5}\right]$-enkephalin potency by amastatin is similar to that by either captopril or phosphoramidon in mouse vas deferens (14). while the magnitude of the enhancement of [Leu $\left.{ }^{5}\right]$-enkephalin potency by 
amastatin is similar to that by captopril but higher than that by phosphoramidon in mouse vas deferens (15).

The reports that naloxone has a high affinity to mu receptors ( $K_{\text {v }}$ values ranging from 1 to $5 \mathrm{nM}$ ) and relatively low affinity to both kappa and delta receptors ( $K_{e}$ values ranging from 10 to $50 \mathrm{nM})(10,13,16,17)$; Mr 2266 has a high affinity to both mu and kappa receptors ( $K_{e}$ values ranging from 1 to $5 \mathrm{nM}$ ) and relatively low affinity to delta receptors $\left(K_{c}\right.$ values ranging from 10 to $\left.50 \mathrm{nM}\right)(10,13$. 17): and $\mathrm{ICl} 154129$ has a relatively high affinity to delta receptors ( $K_{e}$ values renging from 0.1 to $0.9 \mu \mathrm{M})$, the lowest affinity to kappa receptors ( $K_{\mathrm{e}}$ values being more than $20 \mu \mathrm{M})$ and intermediate affinity to mu rereceptors ( $K_{e}$ values ranging from 7 to $8 / M$ ) (13, 18, 19) indicate that dynorphin-(1-8) acts on kappa receptors in guinea-pig ileum and on both kappa and delta receptors in mouse vas deferens.

The fact that the relative importance of the three enzymes in the inactivation of dynorphin- $(1-8)$ is different from that of enkephalins may be caused by the fact that one opioid peptide is hydrolyzed more easily than the other by a particular enzyme as shown by the previous reports (14). although the probability that the relative activity of three enzymes in the vicinity of mu receptors is different from that of kappa receptors can not be neglected since both [Met ${ }^{5}$ - and [Leu ${ }^{5}$ enkephalin have been shown to act on mu receptors in guinea-pig ileum and on delta receptors in mouse vas deferens $(13,16)$, while dynorphin-(1-8) has been suggested to act on kappa receptors in guinea-pig ileum and on both kappa and delta receptors in mouse vas deferens in the present investigation.

The preliminary experiment by employing crude enzyme preparations obtained from membrane fractions of guinea-pig ileum and striatum has shown that dynorphin-(1-8) is hydrolyzed by amastatin-sensitive aminopeptidase at the Tyr-Gly bond, by phosphoramidon-sensitive endopeptidase-24.11 at the Gly-Phe bond, and captopril-sensitive peptidyl dipeptidase $\mathrm{A}$ at both Arg-Arg and Phe-Leu bonds (Hiranuma, T. and Oka, T., unpublished observation). Since [Leu ${ }^{5}$ -
enkephalin-Arg ${ }^{6}$, an initia! hydrolysis product of dynorphin-(1-8) by the captopril-sensitive enzymes, still has essentially the same potency as dynorphin-(1-8) in mouse vas deferens (5), the observation that captopril has significantly enhanced the potency of dynorphin(1-8) in mouse vas deferens indicates that $\left[\right.$ Leu $^{5}$ ]-enkephalin-Arg ${ }^{6}$ is further hydrolyzed by captopril-sensitive peptidase to Tyr-GlyGly-Phe which is reported to have, if any, very weak potency on opioid receptors (20).

All three enkephalin-hydrolyzing enzymes have been suggested to be very closely located to $\mathrm{mu}$ receptors in the guinea-pig ileum (1) and to delta receptors in mouse vas deferens (2) by employing enkephalin which has been indicated to act on mu receptors in guinea-pig ileum $(13,16)$ and delta receptors in mouse vas deferens $(13,16)$. In the present investigation, these three enzymes were indicated to very closely located to kappa receptors in guinea-pig ileum by employing dynorphin-(1-8), which has been suggested to act on kappa receptors in guinea-pig ileum in the present study, since these enzymes have been shown to produce a significant concentration difference of dynorphin-(1-8) between the surrounding organ bath and the vicinity of kappa receptors as demonstrated in Fig. 1, and such concentration difference can be produced only when these inactivating-enzymes are located very closely to kappa receptors. The previous $(1-3)$ and present investigation, therefore, strongly suggest that there are three opioid-peptide-inactivating enzymes in the vicinity of three types of opioid receptors, mu, kappa and delta receptors, as well as an unidentified type of opioid receptor in rat vas deferens.

Acknowledgments: This work was supported in part by both Suzuken Memorial Foundation, and a Grant-in-Aid for Scientific Research from the Ministry of Education. Science and Culture of Japan. The generous gifts of compounds mentioned in Materials and Methods are gratefully acknowledged.

\section{References}

1 Aoki, K., Kajiwara, M. and Oka, T.: The role of bestatin-sensitive aminopeptidase, angiotensin converting enzyme and thiorphan-sensitive "enkephalinase" in the potency of enkephalins in the guinea-pig ileum. Japan. J. Pharmaco!. 36, 
$59-65(1984)$

2 Aoki, K., Kajiwara, M. and Oka, T.: The inactivation of $\left[\mathrm{Met}^{5}\right]$-enkephalin by bestatin-sensitive aminopeptidase. captopril-sensitive peptidy! dipeptidase $A$ and thiorphan-sensitive endopeptidase-24.11 in mouse vas deferens. Japan. J. Pharmacol. 40, 297-302 (1986)

3 Cui, S., Kajiwara, M., Ishii, K., Aoki, K., Sakamoto, J., Matsumiya, T. and Oka, T.: The enhancing effects of amastatin, phosphoramidon and captopril on the potency of $\left[\mathrm{Met}^{5}\right]$-enkephalin in rat vas deferens. Japan. J. Pharmacol. 42, 4349 (1986)

4 Hiranuma, T. and Oka, T.: Effects of peptidase inhibitors on the $\left[\mathrm{Met}^{5}\right]$-enkephalin hydrolysis in ileal and striatal preparations of guinea-pig: Almost complete protection of degradation by the combination of amastatin, captopril and thiorphan. Japan. J. Pharmacol. 41, 437-446 (1986)

5 Corbett, A.D., Paterson, S.J., McKnight, A.T., Magnan, J. and Kosterlitz, H.W.: Dyno:phin ${ }^{1-8}$ and dynorphin ${ }^{1-9}$ are ligands for the $\kappa$-subtype of opiate receptor. Nature 199, 79-81 (1982)

6 McKnight, A.T., Corbett, A.D., Paterson, S.J., Magnan, J. and Kosterlitz, H.W.: Comparison of in vitro potencies in pharmacological and binding assays after inhibition of peptidases reveats that dynorphin (1-9) is a potent $\kappa$-agonist. Life Sci. 31, 1725-1728(1982)

7 Oka, T., Aoki, K. and Kajiwara, M.: The choice of opiaid receptor subtype in isolated preparations by dynorphins. Life Sci. 33, Supp. I, 311-314 (1983)

8 Schulz, R., Wüster, M. and Herz, A.: Receptor preference of dynorphin $A$ fragments in the mouse vas deferens determined by different techniques. J. Pharmacol. Exp. Ther. 230, 200 204 (1984)

9 Miller, L., Rance, M.J., Shaw, J.S. and Traynor, J.R.: Conversion of dynorphin-(1-9) to [Leu ${ }^{5}$ enkephalin by the mouse vas deferens in vitro. Eur. J. Pharmacol. 116, 159-163 (1985)

10 Oka, T., Negishi, K., Suda, M., Sawa, A., Fujino, $M$. and Wakimasu, $M$. Evidence that dynorphin$(1-13)$ acts as an agonist on opioid $x$-receptors. Eur. J. Pharmacol. 77, 137-141, (1982)

11 Oka, T., Negishi, K., Suda, M., Matsumiya, T., Inazu, T. and Ueki, M.: Rabbit vas deferens: A specific bioassay for opioid $k$-receptor agonists.
Eur. J. Pharmacol. 73, 235-236 (1981)

12 Kosterlitz, H.W. and Watt, A.J.: Kinetic parameters of narcotic agonists and antagonists, with particular reference to $\mathrm{N}$-allylnoroxymorphone (naloxone). Br. J. Pharmacol. 33, 266-276 (1968)

13 Kuno, Y., Aoki, K., Kajiwara, M., Ishii, K. and Oka, T.: The relative potency of enkephalins and $\beta$-endorphin in guinea-pig ileum, mouse vas deferens and rat vas deferens after the administration of peptidase inhibitors. Japan. J. Pharmacol. 41. 273-281 (1986)

14 Kuno, Y. and Oka, T.: Estimation of relative importance of three enzymes in the inactivation of [Met ${ }^{5}$-enkephalin and $\left[\mathrm{Met}^{5}\right]$-enkephalin$\mathrm{Arg}^{6}$ in three isolated preparations by employing the inhibitor specific for each enzyme. Japan. J. Pharmacol. 44, 241-247 (1987)

15 Oka, T., Aoki, K., Kajiwara, M., Ishii, K., Kuno, Y., Hiranuma, T. and Matsumiya, T.: Inactivation of [Leu ${ }^{5}$-enkephalin in three isolated preparations: Relative importance of aminopeptidase, endopeptidase-24.11 and peptidyl dipeptidase A. In NIDA Research Monograph 75: Progress in Opioid Research. Edited by Holaday. J.W., Law, P.-Y. and Herz, A., p. 259-262, U.S. Government Printing Office, Washington, D.C. (1986)

16 Lord, J.A.H., Waterfield, A.A., Hughes, J. and Kosterlitz, H.W.: Endogenous opioid peptides: multiple agonists and receptors. Nature 267. 495-499 (1977)

17 Oka, T., Negishi, K., Kajiwara, M., Watanabe, Y., Ishizuka, Y. and Matsumiya, T.: The choice of opiate receptor subtype by neo-endorphins. Eur. J. Pharmacol. 79, 301-305 (1982)

18 Shaw, J.S., Miller, L., Turnbull, M.J., Gormley, J.J. and Morley, J.S.: Selective antagonists at the opiate delta-receptor. Life Sci. 31, 12591262 (1982)

19 Ueki, M., Aoki, K., Kajiwara, M., Shinozaki, K., Inoue, $H$. and Oka, T.: Two new opioid deltareceptor ligands: a highly selective agonist and a potent selective antagonist in in vitro isolated preparations. Japan. I. Pharmacol. 36, 485-489 (1984)

20 Morley, J.S.: Structure-activity relationships of enkephalin-like peptides. Annu. Rev. Pharmacol. Toxicol. 20, 81-110 (1980) 